\title{
Unresectable Metastatic Colorectal Cancer Treatment and Survival - Pauls Stradins Clinical University Hospital Experience
}

\author{
Skuja Elina*/**, Purkalne Gunta*/**, Miklasevics Edvins*/** \\ *Institute of Oncology, Riga Stradins University, Latvia \\ **Pauls Stradins Clinical University Hospital, Riga, Latvia
}

\section{Summary.}

Introduction. Despite recent advances in the medical treatment of metastatic colorectal cancer (mCRC), which include oxaliplatinand irinotecan-based first-line regimens and the increasing use of targeted monoclonal antibodies, survival rates for patients with $\mathrm{mCRC}$ remain unacceptably low.

Aim of the Study. Is to analyze survival in patients with unresectable metastatic colorectal cancer.

Materials and Methods. Retrospective study of unresectable metastatic colorectal cancer patients who underwent palliative chemotherapy in Clinic of Oncology of PaulsStradins Clinical University Hospital from 2004 to 2011 was done.

Results.102 patients had a median PFS of 8 months and median OS of 16 months. Subgroup analysis revealed median PFS of 9 months in the synchronous metastatic disease group and 7 months in the metachronous metastatic disease group $(p=0.0089)$ and median OS of 16 months and 12 months, respectively ( $p=0.0168)$. Median OS was 11 months in patients received only one line palliative chemotherapy compared to 19 months in patients received more than one line therapy $(p<0.0001)$.

Conclusions. The parameter of synchronous and metachronous metastases is of prognostic value in mCRC patients.Second line palliative chemotherapy prolongs overall survival in patient with $\mathrm{MCRC}$.

Key words: Metastatic colorectal cancer, palliative chemotherapy, synchronous and metachronous metastatic disease

\section{INTRODUCTION}

Mortality from colon cancer has decreased over the past 30 years, but there is still a huge heterogeneity in survival rates that can be mainly explained by patient and tumor characteristics, host response factors, and treatment modalities. At the time of diagnosis, approximately $25 \%$ of the patients already have manifest metastases and almost $50 \%$ will develop them following treatment of the colorectal primary [4].

Without treatment, life expectancy is usually $<1$ year. The management of unresectable metastatic colorectal cancer (mCRC) is a global treatment strategy, which applies several lines of therapy, salvage surgery and maintenance therapy, in order to prolong overall survival and control symptoms. With modern chemotherapeutic agents, median overall survival (OS) currently reaches 16-22 months [1, 2].

The synchronous presence of primary colon cancer and metastasis may indicate a more disseminated disease status and is associated with a shorter progression free survival (PFS) than metachronous presence of metastasis [3].

\section{AIM OF THE STUDY}

The aim of present study is to characterize survival data in patients with unresectable metastatic colorectal cancer.

\section{MATERIAL AND METHODS}

This retrospective review included 102 patients with metastatic colon and rectal cancer who received palliative chemotherapy at the Pauls Stradins Clinical University Hospital between January 2004 and December 2011. Patients who have had surgery or chemoembolisation for metastatic lesions were excluded. Data were retrieved from each patient's medical records, and included characteristics of the primary and metastatic tumor, chemotherapy information, long-term outcome progression free survival (PFS) and overall survival (OS).Patients were considered evaluable for study if they had completed at least 2 cycles of chemotherapy. A cut-off value of 6 months after the initial diagnosis to define a metachronous metastatic disease was selected. Overall survival and progression free survival rates were estimated using the Kaplan-Meier method. The logrank test was used to calculate any significant difference between the subgroups by univariate analysis. Significance levels were set at $\mathrm{P}<0.05$. All statistical analyses were performed by using MedCalc.

\section{RESULTS}

One hundred and two patients with metastatic colorectal cancer were analyzed. $65(63.7 \%)$ patients demonstrated synchronous metastatic disease, while 37 $(36.3 \%)$ patients were developed metastases after the primary diagnosis of colorectal cancer.

Patients in the total study group $(n=102)$ had an estimated progression free survival (PFS) of 8 months 
and 1 year PFS of $14.6 \%$ and estimated overall survival (OS) of 16 months and 1-year OS of $61.8 \%$ and 2-year OS of $14.9 \%$.

There were seen increased $\operatorname{PFS}(\mathrm{p}=0.0089 ;$ HR 0.45 ; $95 \%$ CI $0.26-0.82)$ and $\mathrm{OS}(\mathrm{p}=0.0168 ; \mathrm{HR}=0.51 ; 95 \% \mathrm{CI}$ 0.30-0.89) in synchronous compared to metachronous metastatic disease group. Median PFS and median OS were 9 and 16 months in the synchronous metastatic disease group, and 7 and 12 months in the metachronous metastatic disease group. The 1-year PFS was $19.1 \%$ and $4.7 \%$ in the synchronous compared to metachronous metastatic disease group (Fig.1). The 1-year OS was $71 \%$ and $44.4 \%$ in the synchronous compared to metachronous metastatic disease group and 2-year OS was $18.3 \%$ and $0 \%$ (Fig. 2 ).

First line palliative chemotherapy received all patients. Oxaliplatin combinations (FOLFOX4, FOLFOX6, mFOLFOX6, oxaliplatin + tegafur) received $72.2 \%$, irinotecan combinations (FOLFIRI, irinotecan mono) $-10.3 \%$, but fluoropyrimidines monotherapy (capecitabine, $5 \mathrm{FU}$, tegafur) $-17.5 \%$ of all patients. A small difference in OS and PFS was observed between subgroups (Table 1 ).

Significant OS difference was observed in metastatic colorectal cancer patients received more than one line of palliative chemotherapy. $50 \%(n=51)$ of all patient received second line chemotherapy. $23.53 \%$ received fluoropyrimidines, but $76.47 \%$ received oxaliplatin and irinotecan containing chemotherapy. Median OS was 11 months in patients received only one line palliative chemotherapy compared to 19 months in patients received combined oxaliplatin or irinotecan containing chemotherapy or fluoropyrimidines(capecitabine, tegafur, 5FU) monotherapy $(\mathrm{p}<0.0001)$ (Table 2). 1-year OS and 2-year OS was $80.7 \%$ and $26.3 \%$ in patients received more than one line of chemotherapy and $40.5 \%$ and $0 \%$ in patients received only one line of chemotherapy (Fig. 3)

The difference in OS in all patients group between fluoropyrimidines monotherapy and combined cytotoxic treatment was not observed. Median OS was 19 months in both groups $(\mathrm{p}=0.36)$ (Fig 3).

Subgroup analysis revealed statistically significant decrease in OS in patients received only one line of palliative chemotherapy in synchronous metastatic disease group. In the metachronous metastatic disease group the difference was observed, but without statistical significance (Table 3 ).

Targeted therapy impact on survival was analyzed. $13.6 \%$ of all patients received one of monoclonal antibodies (bevacizumab or cetuximab) in the first line setting. Difference in PFS or OS was not observed (Table 4).

\section{DISCUSSION}

In this retrospective study we demonstrated our experience in metastatic colorectal cancer treatment. While surgery is the cornerstone treatment for early stage colorectal cancer, chemotherapy is the first treatment option for metastatic disease when tumor lesions are not resectable at presentation.

Median PFS in first line FOLFOX or FOLFIRI chemotherapy trials reached 8.4 months and median OS 18 months [2]. The addition of bevacizumab or antiEGFR to oxaliplatin based or irinotecan based first line chemotherapy improve progression free survival to 10.6 months and the overall survival to 21.3 months $[8,9]$. In patients with KRAS wild-type tumors, the addition of cetuximab to either FOLFIRI or FOLFOX produced an improvement in median PFS (9.9 months) and median OS (23.5 months) [10,11]. Similarly, the addition of panitumumab to FOLFOX is superior to FOLFOX alone in terms of PFS [12].

In our study median PFS of 8 months and median OS of 16 months is similar to survival observed in large first line chemotherapy trials. The addition of targeted agents did not show an improvement in median PFS or OS. This fact could be explained due to small number of patients received cetuximab or bevacizumab in the first line palliative treatment.

Only few data have been reported on the prognostic role of synchronous and metachronous metastases in patients with mCRC treated with chemotherapy. Several authors showed no prognostic role for these parameters $[2,14,17]$, whereas others identified metachronous disease as a favorable prognostic parameter $[15,16]$.

There are several studies showing no difference in disease free and overall survival rates between the synchronous and metachronous mCRC after liver resection $[5,6]$.

Current study demonstrated shorter PFS and OS in patients with metachronous mCRC. This finding could be explained with fact that a significant percentage of patients with metachronous metastases were treated with prior adjuvant chemotherapy, whereas patients with synchronous metastases obviously were not. This may have resulted in a resistance to chemotherapy in metachronous mCRC group.

Survival of CRC patients could be influenced by a difference in the presence of prognostic molecular markers between patients with synchronous vs. metachronous metastases [13].

Most patients should be offered second line therapy when tumor progression or unacceptable toxicity stops first line therapy. Our study demonstrated significant overall survival benefit in patient received second line chemotherapy compared to patient who were administered only one line of palliative chemotherapy. Our knowledge in treatment of unresectable metastatic colorectal cancer is based on clinical trials performed in selected populations, of younger age, and with less comorbidity than the general metastatic colorectal cancer population. Analysis of current retrospective study included unselected patient population with different treatment strategies and survival outcome. 


\section{CONCLUSIONS}

1. Survival data (PFS and OS) is equal to large trial data of first line palliative chemotherapy. Addition of targeted agents in first line settings could improve PFS and OS.

2. The parameter of synchronous and metachronous metastases is of prognostic value in mCRC patients. Possible explanations of decreased survival include a chemotherapy resistance in patients with metachronous disease because of prior adjuvant treatment.

3. Second line palliative chemotherapy prolongs overall survival in patient with mCRC

\section{Conflict of interest: None}

\section{REFERENCES:}

1. Falcone A, Ricci S, Brunetti I, Pfanner E, Allegrini G, Barbara C, Crinò L, Benedetti G, Evangelista W, Fanchini L, Cortesi E, Picone V, Vitello S, Chiara S, Granetto C, Porcile G, Fioretto L, Orlandini C, Andreuccetti M, Masi G; Gruppo Oncologico Nord Ovest. Phase III trial of infusional fluorouracil, leucovorin, oxaliplatin, and irinotecan (FOLFOXIRI) compared with infusional fluorouracil, leucovorin, and irinotecan (FOLFIRI) as first-line treatment for metastatic colorectal cancer: the Gruppo Oncologico Nord Ovest // J ClinOncol 2007; 25: 1670-1676

2. Tournigand C, André T, Achille E, Lledo G, Flesh M, Mery-Mignard D, Quinaux E, Couteau C, Buyse M, Ganem G, Landi B, Colin P, Louvet C, de Gramont A. FOLFIRI followed by FOLFOX6 or the reverse sequence in advanced colorectal cancer: a randomized GERCOR study // J Clin Oncol 2004; 22: $229-37$

3. Ming-ShianT, Yen-HaoS, Ming-Chih $\mathrm{H}$, Jin-Tung L., Tzu-Ping C., Hong-Shiee L., Po-Huang L. Clinicopathological Features and Prognosis in Resectable Synchronous and Metachronous Colorectal Liver Metastasis. // Annals of Surgical Oncology 2007; 14(2):786-794

4. Van Cutsem E, Oliveira J, and on behalf of the ESMO Guidelines Working Group: Advanced colorectal cancer: ESMO Clinical Recommendations for diagnosis, treatment and follow-up. // Ann Oncol 2009;20: iv61-iv63

5. van der Pool AEM, Lalmahomed ZS, Ozbay Y, de Wilt JHW, Eggermont AMM, Jzermans JNM, Verhoef C. 'Staged' liver resection in synchronous and metachronouscolorectal hepatic metastases: differences in clinicopathological features and outcome // Colorectal Dis 2010;12(10): e229-35

6. Bockhorn M, Frilling A, Frühauf NR, Neuhaus J, Molmenti E, Trarbach T, Malagó M, Lang H, Broelsch CE. Survival of patients with synchronous and metachronous colorectal liver metastases-is there a difference? // J Gastrointest Surg 2008;12(8):1399405

7. Buyse M, Burzykowski $\mathrm{T}$, Carroll $\mathrm{K}$, Michiels $\mathrm{S}$, Sargent DJ, Miller LL, Elfring GL, Pignon JP,
Piedbois P. Progression-free survival is a surrogate for survival in advanced colorectal cancer. // J Clin Oncol 2007;25(33):5218-24

8. SaltzLB, ClarkeS, Diaz-RubioE, ScheitauerW, Figer A, Wong R Koski S, Lichinitser M, Yang TS, Rivera F, Couture F, Sirzén F, Cassidy J. Bevacizumab in combination with oxaliplatin-based chemotherapy as first-line therapy in metastatic colorectal cancer: a randomized phase III study. //J ClinOncol2008;26: 2013-2019

9. HurwitzH, Fehrenbacher L, Novotny W, Cartwright T, Hainsworth J, Heim W,Berlin J, Baron A, Griffing S, Holmgren E, Ferrara N, Fyfe G, Rogers B, Ross R, Kabbinavar F. Bevacizumab plus irinotecan, fluorouracil, and leucovorin for metastatic colorectal cancer. //N Engl J Med2004;350: 2335-2342

10. Van Cutsem E, Köhne CH, Hitre E, Zaluski J, Chang Chien CR, Makhson A, D’Haens G, Pintér T, Lim R, Bodoky G, Roh JK, Folprecht G, Ruff P, Stroh C, Tejpar S, Schlichting M, Nippgen J, Rougier P. Cetuximab and chemotherapy as initial treatment for metastaticcolorectal cancer. // N Engl J Med 2009; 360(14):1408-17

11. Bokemeyer C, Bondarenko I, Makhson A, Hartmann JT, Aparicio J, de Braud F, Donea S, Ludwig H, Schuch G, Stroh C, Loos AH, Zubel A, Koralewski P. Fluorouracil, leucovorin, and oxaliplatin with and without cetuximab in the first-line treatment of metastaticcolorectal cancer. // J ClinOncol 2009; 27(5):663-71

12. Douillard JY, Siena S, Cassidy J, Tabernero J, Burkes R, Barugel M, Humblet Y, Bodoky G, Cunningham D, Jassem J, Rivera F, Kocákova I, Ruff P, Błasińska-Morawiec M, Šmakal M, Canon JL, Rother M, Oliner KS, Wolf M, Gansert J. Randomized, phase III trial of panitumumab with infusional fluorouracil, leucovorin, and oxaliplatin (FOLFOX4) versusFOLFOX4alone as first-linetreatment in patients with previouslyuntreatedmetastaticcolorectal cancer: the PRIMEstudy. // J ClinOncol 2010;28(31):4697705

13. Pantaleo MA, Astolfi A, Nannini M, Paterini P, Piazzi G, Ercolani G, Brandi G, Martinelli G, Pession A, Pinna AD, Biasco G. Gene expression profiling of liver metastases from colorectal cancer as potential basis for treatment choice. // Br J Cancer 2008;99: 1729-1734

14. Colucci G, Gebbia V, Paoletti G, Giuliani F, Caruso M, Gebbia N, Carteni G, Agostara B, Pezzella G, Manzione L, Borsellino N, Misino A, Romito S, Durini E, Cordio S, Di SM, Lopez M, Maiello E, Montemurro S, Cramarossa A, Lorusso V, Di BM, Chiarenza M, Valerio MR, Guida T, Leonardi V, Pisconti S, Rosati G, Carrozza F, Nettis G, Valdesi M, Filippelli G, Fortunato S, Mancarella S, Brunetti C. Phase III randomized trial of FOLFIRI vs FOLFOX4 in the treatment of advanced colorectal cancer: a multicenter study of the Gruppo Oncologico Dell'Italia Meridionale. // J ClinOncol2005;23 4866-4875 
15. Etienne-Grimaldi MC, Formento JL, Francoual M, Francois E, Formento P, Renee N, Laurent-Puig P, Chazal M, Benchimol D, Delpero JR, Letoublon C, Pezet D, Seitz JF, Milano G. K-Ras mutations and treatment outcome in colorectal cancer patients receiving exclusive fluoropyrimidine therapy. // Clin Cancer Res 2008; 14: 4830-4835

16. Freyer G, Rougier P, Bugat R, Droz JP, Marty M, Bleiberg H, Mignard D, Awad L, Herait P, Culine S, Trillet-Lenoir V. Prognostic factors for tumour response, progression-free survival and toxicity in metastatic colorectal cancer patients given irinotecan (CPT-11) as second-line chemotherapy after 5FU failure. CPT-11 F205, F220, F221 and V222 study groups. // Br J Cancer 2000;83: 431437

17. Mekenkamp JM, Koopman $M$, Teerenstra S, van Krieken JHJM, Mol L, Nagtegaal ID, Punt CJA. Clinicopathological features and outcome in advanced colorectal cancer patients with synchronous vs metachronous metastases. // Br J Cancer2010;103(2): 159-164.

\section{Address:}

Elīna Skuja

Clinic of Oncology,

Pauls Stradins Clinical University Hospital,

Pilsoņu Street 13, LV1002,

Riga, Latvia

E-mail: elina.skuja@stradini.lv

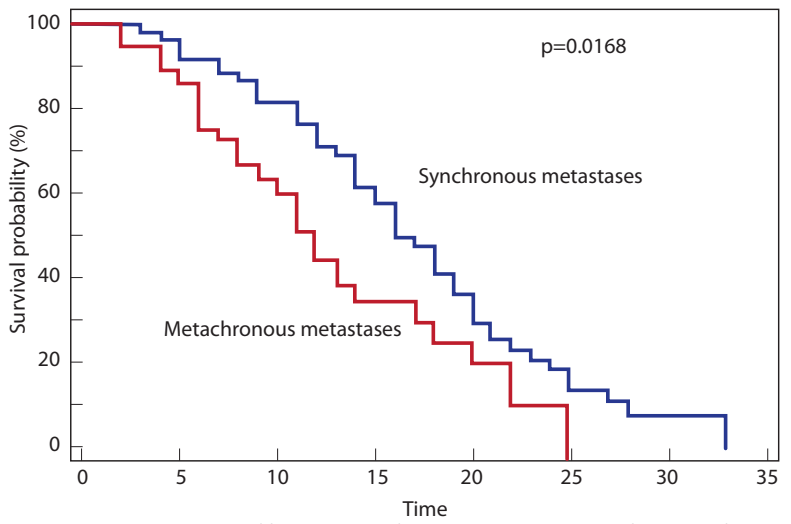

Fig. 1.Overall survival in patients with synchronous and metachronous metastatic disease.

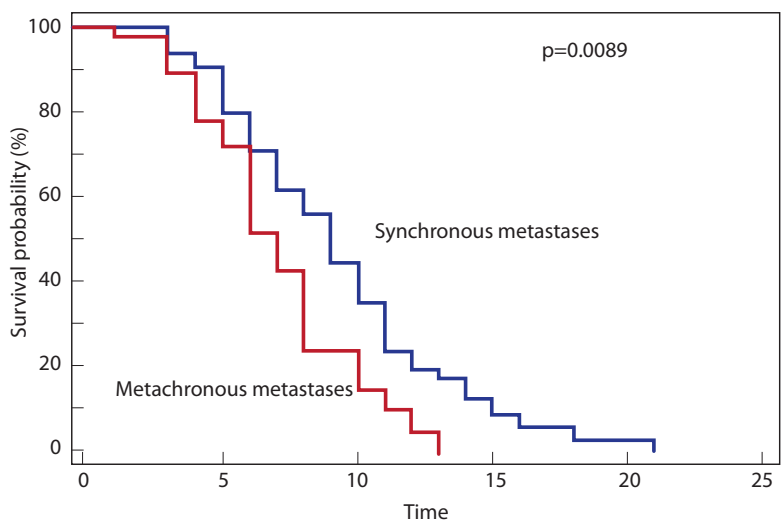

Fig. 2. Progression free survival in patients with synchronous and metachronous metastatic disease

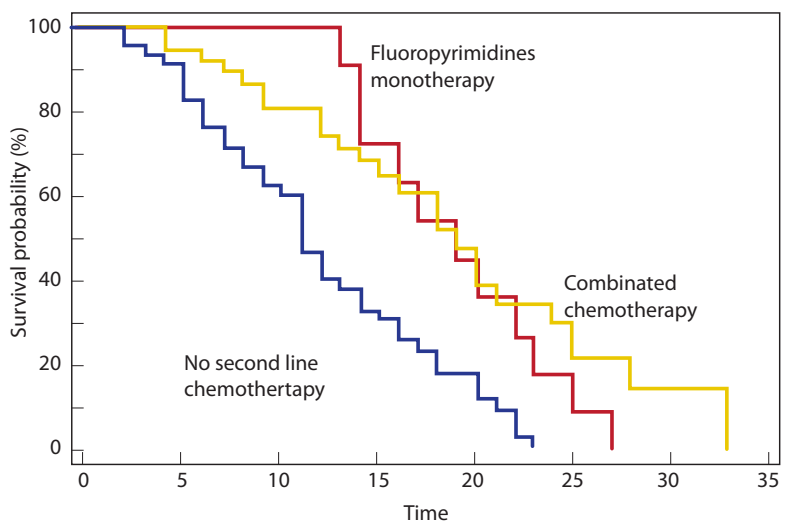

Fig 3. Overall survival in all patients received second line chemotherapy. 
Table 1. Median overall survival and progression free survival in patients with synchronous and metachronous metastatic disease received different treatment schedules in the first line settings.

\begin{tabular}{|l|c|c|c|c|}
\hline & $\begin{array}{c}\text { Oxaliplatin } \\
\text { containing } \\
\text { regiments }\end{array}$ & $\begin{array}{c}\text { Fluoro- } \\
\text { pyrimidines } \\
\text { mono- } \\
\text { therapy }\end{array}$ & $\begin{array}{c}\text { Irinotecan } \\
\text { containing } \\
\text { regiments }\end{array}$ & $\mathrm{p}$ \\
\hline Median OS & $\mathbf{1 6}$ months & $\mathbf{1 6}$ months & $\mathbf{1 4}$ months & $\mathbf{0 . 4 7}$ \\
$\begin{array}{l}\text { Synchronous } \\
\text { group } \\
\text { Meta- } \\
\text { chronous } \\
\text { group }\end{array}$ & 18 months & 16 months & 14 months & 0.26 \\
\hline $\begin{array}{l}\text { Median } \\
\text { PFS }\end{array}$ & $\mathbf{8}$ months & $\mathbf{1 1}$ months & $\mathbf{7}$ months & $\mathbf{0 . 0 5 6}$ \\
$\begin{array}{l}\text { Synchronous } \\
\text { group } \\
\begin{array}{l}\text { Meta- } \\
\text { chronous } \\
\text { group }\end{array}\end{array}$ & 7 months & 11 months & 7 months & 0.059 \\
\hline
\end{tabular}

Abbreviations in the table: OS, overall survival; PFS, progression free survival

Table 2. Median overall survival in patients with synchronous and metachronous metastatic disease received one or more than one line of palliative chemotherapy.

\begin{tabular}{|l|l|l|l|l|l|}
\hline & $\begin{array}{l}\text { 1 line of } \\
\text { chemo- } \\
\text { therapy }\end{array}$ & $\begin{array}{l}\geq 2 \text { lines of } \\
\text { c hemo- } \\
\text { therapy }\end{array}$ & HR & $95 \%$ CI & $\mathrm{p}$ \\
\hline $\begin{array}{l}\text { Median } \\
\text { OS }\end{array}$ & $\begin{array}{c}\mathbf{1 1} \\
\text { months }\end{array}$ & $\begin{array}{c}\mathbf{1 9} \\
\text { months }\end{array}$ & $\mathbf{0 . 3 3}$ & $\mathbf{0 . 2 0 - 0 . 5 6}$ & $<\mathbf{0 . 0 0 0 1}$ \\
$\begin{array}{l}\text { Synchro- } \\
\text { nous } \\
\text { group } \\
\begin{array}{l}\text { Meta- } \\
\text { chronous } \\
\text { group }\end{array}\end{array}$ & 12 months & 20 months & 0.20 & $\begin{array}{l}0.09774 \text { to } \\
0.4140\end{array}$ & $<0.0001$ \\
\hline
\end{tabular}

Abbreviations in the table: OS, overall survival; HR, hazard ratio; CI, confidence interval
Table 3. Median overall survival in patients with synchronous and metachronous metastatic disease received one or more than one line of palliative chemotherapy.

\begin{tabular}{|l|l|l|l|l|}
\hline & $\begin{array}{l}\text { No second } \\
\text { line } \\
\text { therapy }\end{array}$ & $\begin{array}{l}\text { Fluoro- } \\
\text { pyrimidines } \\
\text { mono- } \\
\text { therapy }\end{array}$ & $\begin{array}{l}\text { Combined } \\
\text { second } \\
\text { line } \\
\text { therapy }\end{array}$ & $\mathrm{p}$ \\
\hline Median OS & $\begin{array}{c}\mathbf{1 1} \\
\text { months } \\
12\end{array}$ & $\mathbf{1 9}$ months & $\begin{array}{c}\mathbf{1 9} \\
\text { months } \\
20\end{array}$ & $\mathbf{0 . 0 0 0 5}$ \\
$\begin{array}{l}\text { Synchro- } \\
\text { nous group } \\
\begin{array}{l}\text { Meta- } \\
\text { chronths } \\
\text { group }\end{array}\end{array}$ & $\begin{array}{c}11 \\
\text { months }\end{array}$ & $\begin{array}{c}17.5 \\
\text { months } \\
\text { months }\end{array}$ & $\begin{array}{c}13 \\
\text { months }\end{array}$ & 0.57 \\
\hline
\end{tabular}

Abbreviations in the table: OS, overall survival

Table 4. Median overall survival and progression free survival in patients with synchronous and metachronous metastatic disease received chemotherapy (CT) with or without targeted therapy (bevacizumab or cetuximab) in first line palliative settings.

\begin{tabular}{|c|c|c|c|c|c|}
\hline & $\begin{array}{l}\text { Targeted } \\
\text { therapy }+ \\
\text { CT }\end{array}$ & CT & HR & $95 \% \mathrm{CI}$ & $\mathrm{p}$ \\
\hline $\begin{array}{l}\text { Median } \\
\text { OS }\end{array}$ & $\begin{array}{c}15 \\
\text { months }\end{array}$ & $\begin{array}{c}16 \\
\text { months }\end{array}$ & 0.9449 & $\begin{array}{c}0.4516- \\
1.9769\end{array}$ & 0.8803 \\
\hline $\begin{array}{l}\text { Meta- } \\
\text { chronous } \\
\text { group }\end{array}$ & $\begin{array}{c}11 \\
\text { months }\end{array}$ & $\begin{array}{c}12 \\
\text { months }\end{array}$ & 1.1481 & $\begin{array}{c}0.4602- \\
2.8645\end{array}$ & 0.7672 \\
\hline $\begin{array}{l}\text { Sync- } \\
\text { hronous } \\
\text { group }\end{array}$ & $\begin{array}{c}15 \\
\text { months }\end{array}$ & $\begin{array}{c}16 \\
\text { months }\end{array}$ & 1.2159 & $\begin{array}{c}0.3159- \\
4.6796\end{array}$ & 0.7762 \\
\hline $\begin{array}{l}\text { Median } \\
\text { PFS }\end{array}$ & 9 months & 8 months & 0.9413 & $\begin{array}{c}0.4765- \\
1.8593\end{array}$ & 0.8617 \\
\hline $\begin{array}{l}\text { Meta- } \\
\text { chronous } \\
\text { group }\end{array}$ & 7 months & 7 months & 1.0103 & $\begin{array}{c}0.3847- \\
2.6531\end{array}$ & 0.9834 \\
\hline $\begin{array}{l}\text { Sync- } \\
\text { hronous } \\
\text { group }\end{array}$ & $\begin{array}{c}10 \\
\text { months }\end{array}$ & 9 months & 1.1504 & $\begin{array}{c}0.4461- \\
2.9666\end{array}$ & 0.7719 \\
\hline
\end{tabular}

Abbreviations in the table: OS, overall survival; PFS, progression free survival; HR, hazard ratio; CI, confidence interval; CT, chemotherapy 